\title{
Sovereignty at Stake? The European Commission's proposal for a Defence and Security Procurement Directive
}

\author{
The Defence and Security Procurement Directive (DSDP) is the first \\ supranational policy in the Common Security and Defence Policy (CSDP) and \\ represents a departure from the standard understanding of the CSDP as \\ intergovernmental. Whilst the member states were initially against such an \\ initiative, the Defence Directive was eventually proposed in the Council in 2007 \\ and accepted in July 2009. This paper examines why EU member states changed \\ their position on the proposal for a Defence and Security Procurement Directive \\ between 2004 and 2007. The analysis builds upon two hypotheses that aim to \\ account for this change in position. Providing new insight into the views of the \\ member states, the study finds that member states accepted the Directive due to a \\ sense of obligation to respect internal market rules, and further discusses the \\ theoretical implications of these findings.
}

Keywords: defence procurement; European Commission; cost benefit analysis; Common Security and Defence Policy; Defence and Security Procurement Directive

\section{Introduction}

The policy making process of the European Union's (EU) Common Security and Defence Policy (CSDP) is considered intergovernmental (Risse-Kappen 1996, p. 67; Øhrgaard 1997, p. 8; Sjursen 2011). In this policy process, the member states are expected to be reluctant to move their decision capacity to the European level, and it is widely regarded that there should be no role for supranational institutions. In recent years, however, this understanding has been contested by scholars who argue that there is an increase in engagement of the European Commission in the Common Foreign and Security Policy (CFSP) (Dijkstra 2011, Blauberger and Weiss 2013, Riddervold 2015, Weiss and Blauberger 2016). This paper contributes to this literature by examining a policy initiative of the European Commission in the area of CSDP, which is the first supranational legislation in the field of defence and security: the Defence and Security Procurement Directive (2009/81 EC). ${ }^{1}$

Two features of the defence procurement practice in Europe make the acceptance of a proposal for the DSDP (or Directive) surprising. First of all, until the 
acceptance of the Directive, the defence procurement practice was intergovernmental (Britz 2010). The acquisition of defence material was organized through voluntary, nonbinding agreements such as the Letter of Intent Framework, the OCCAR, and, more recently, the European Defence Agency (EDA) Code of Conduct. Furthermore, defence procurement had been marked by measures of protectionism. Consequently, when the European Commission (Commission) proposed a defence industry strategy, the member states argued that this strategy was premature (Communication 2003). In response to a Green Paper from the Commission in 2004, the United Kingdom (UK) and France voiced that they saw no need for a Directive. Secondly, central to the issue of defence procurement has been the use of article 346 TFEU. This article stipulates that the member states, on the basis of an essential national security interest, are able to derogate their defence contracts from the Treaty. ${ }^{2}$ Member states have made frequent use of this legal measure to take the acquisition of defence goods outside the scope of the Internal Market.

The Directive, eventually accepted in 2009, makes it more difficult to justify the need for the use article 346 in practice (Trybus 2014) and replaces voluntary agreements with a new legally binding framework. Yet in response to the Commission Green Paper in 2004 member states expressed the preference for intergovernmental cooperation. In the years after this consultation, member states moved from not wanting a Directive to accepting the proposal of the Commission, that is, changed their position. This paper clarifies and accounts for the move from intergovernmental cooperation to the acceptance of a supranational legal framework in the field of defence and security, and asks: why did member states change their position on the proposal for a Directive? ${ }^{3}$ The acceptance of the proposal for a Directive challenges the understanding of the CSDP as intergovernmental, highlighting that the regulations in the field of defence and security have intervened in an area of core state powers (Genschel and Jachtenfuchs 2013).

Previous research on the Directive emphasizes the role of the Commission (Weiss 2013, Muravaska 2014), using case law to drive member states to accept the Directive in 2009 (Blauberger and Weiss 2013, Weiss and Blauberger 2016). Others have highlighted the role of the French Presidency in the accepting of the Directive (Hoeffler 2011). Furthermore, several extensive studies have placed the Directive in its legal context (Heuninckx 2015, Trybus 2014). Building on these important findings, the main contribution of this paper is the empirical data from four different member states. The focus on member states is significant as we expect the CSDP policy to be in the 
hands of member states. By using this data from these member states on the acceptance of the Directive, the paper brings new knowledge to the field.

The four member states studied are the Netherlands, France, Sweden and the UK. These member states are selected because the UK and France openly rejected more involvement for the Commission, and both countries have large defence industries, which makes their view on the Directive significant. Sweden is one of the six largest defence producers in Europe and a signatory to the Letter of Intent Framework (Britz 2010). The Dutch defence industry consists mainly of Small and Medium Enterprises (SMEs), dependent on subcontracting, and the acceptance of a Directive would challenge this practice. This paper systematically studies these member states and gives insight in to why these member states decided to accept a policy that challenges their sovereignty. The study clarifies that some member states were well aware of the Commission's initiatives and were at certain stages very much engaged in the process.

The next part of this paper presents a short overview of the creation of the Directive and the responses of the member states. The second part establishes a theoretical framework drawing on two approaches that may account for change in member state position, and the eventual acceptance. In the third part, I examine whether this acceptance was based on cost-benefit calculations. From this perspective, the Directive was expected to enhance the economic position of member states. It is also investigated if member states were led by certain norms, possibly viewed more important than the norm of sovereignty. The fourth and final part discusses the theoretical implications and limitations of these findings, and makes some suggestions as to how the theoretical underpinnings of this analysis might be further strengthened.

\section{The Defence and Security Procurement Directive}

Prior to the Directive, the Commission had been very active in promoting further integration of the European defence equipment market (Political Union 1990; Communication 1997, 2003, 2005, 2007). Already in 1990, the Commission, with the goal to eventually bring defence equipment under the common market principles, proposed the removal of article 346 TFEU (at that time article 223) (Political Union 1990). This initiative was followed by two communications, in 1996 and 1997, in which the Commission expressed the aim to facilitate the development of cooperation in the defence industry sector (Communication 1996, 1997). An Action Plan accompanied the latter communication which the Commission requested to be discussed by the Council. 
Member states were, however, not willing to discuss these proposals and the Council never reviewed the document (Mörth 2003, p. 43; Eisenhut 2009, p. 115). Furthermore, member states claimed that the ideas and initiatives from the Commission were premature (Communication 2003, Mawdsley 2003). A new communication in 2003 introduced the potential added value of a legislative initiative for the first time. It was decided that the decision to implement such a measure should be made after an impact assessment (Communication 2003). This assessment was conducted by means of a Green Paper wherein the Commission asked for feedback on the possible creation of a separate Directive (Green Paper 2004).

The response of the member states to the creation of a Directive is contradictory and puzzling. Since on the one hand, the reply to the Green Paper consisted of the acceptance of an open European Defence Equipment Market (EDEM). This is reflected in the replies by for example Germany (Bundesrepublik Deutschland 2005), France (Représentation Permanente 2005), Britain (MoD 2005), Sweden (Nämden för Offentlig Upphandling 2004) and the Netherlands (Interview Dutch official, 24 February 2015). The French response emphasised that practices of harmonization, transparency and openness are desirable and congratulates the Commission on the publication of the Green Paper (Représentation Permanente 2005). On the other hand: "France considers the best way to make real progress (in armaments cooperation) would be to focus on an experimental and intergovernmental instrument" (Security and Defence Agenda 2005, Représentation Permanente 2005). Also the UK underlined the fundamental need to improve the transparency and openness of the EDEM (MoD 2005, European Standing Committee B 2005). Therefore, the UK government considered the Green paper an important instrument in the process of improving defence equipment procurement in the EU (European Standing Committee B 2005). At the same time the government argued for alternative (intergovernmental) approaches to create a more open and transparent EDEM through, for example, the creation of the EDA.

Despite increasing positivity towards the Commission's proposal and the development of openness and transparency in the area of defence procurement, the UK and France had their reservations. Therefore, as part of the same response to the Green Paper, these member states remained resolute in favouring intergovernmental solutions (Représentation Permanente 2005, MoD 2005). The results the Commission published gave the impression that most member states had changed their position and welcomed integration (Communication 2005). However, member states’ documents indicate that it 
remained contested whether there should be a role for the Commission and whether this policy belonged under the former First Pillar of the EU. The former defence minister of the UK had underlined this preference for intergovernmental cooperation and insisted that: "European defence and security should remain the preserve of EU governments alone"; that is to say: without any role for the Commission or the European Parliament (Cornish 1995, p. 73). The same objective is also expressed in the Treaty of Amsterdam (Official Journal of the European Union 1997), where member states stated that "The progressive framing of a common defence policy will be supported, as Member States consider appropriate, by cooperation between them in the field of armaments" (TEU article 17, emphasis added). In the eyes of France and the UK, further integration in this policy area should emerge without a role for the Commission.

With member states welcoming an open defence equipment market in the 2004 Green Paper, a change from the reluctance in the nineties seemed to have taken place. However, both the UK and France did express the preference for intergovernmental solutions in 2004. As the Directive was introduced in the 2004 Green Paper, it is possible to trace the response of the member states from the first introduction until the Directive was proposed and accepted in the Council. The above has also illustrated that between 2004 and 2007 the positions of member states changed and that they came to accept a supranational policy. It was during these years that they agreed to position an issue area defined as part of the national prerogative under the control of a supranational institution.

\section{Moving beyond intergovernmentalism}

The move from intergovernmental to supranational integration in the area of defence equipment procurement could be regarded as a case of creeping competences. Previous studies consider that creeping competence in regulatory policy is caused by a functional spill over (Pollack 1994, Citi 2014). Differently, this paper argues that there was deliberate action from both the Commission and the member states in this move.

In order to account for European integration more generally, that is, why member states have transferred parts of their sovereignty to the European level, research has focused on explanations based on the explanation that such a move is in the selfinterest of a state (Lange 1993, Moravcsik 1998). In particular in the area of CSDP, a policy area so closely attached the national sovereignty, and based on intergovernmental cooperation, self-interest is expected to be able to explain cooperation. The starting 
point in this analysis is therefore a rational choice perspective. A rational choice perspective assumes that preferences remain constant over time. However, to account for the eventual acceptance of the Directive by member states it is expected that preferences have changed between 2004 and 2007. Therefore an alternative perspective is introduced, complimentary to the rational choice perspective. This alternative approach is chosen as studies on the CFSP have suggested that actors in this policy area are also led by norms (Cross 2015, Riddervold 2011, Sjursen 2002). This study, therefore, develops and makes use of the understanding of entrapment: that member states were entrapped in accepting the Directive. The use of such an approach allows for the analysis of the acceptance of the Directive based on the idea of member states as norm (rule) followers. Entrapment was then possible as a consequence of previously made commitments in the context of the European integration.

\section{Cost benefit considerations}

A rational choice perspective accounts for political action by supposing that actors are rational and seek to maximize their utility (Elster 1986, Eriksen 2011). Actors make choices that are in their self-interest, based on calculations of expected costs and benefits (Howlett et al. 2009). These costs and benefits can be either economic or social. Furthermore, preferences or self-interest are assumed to remain constant over a period of time. In the context of European integration it is expected that member states will only accept a supranational policy when it is in their self-interest. The DSDP is a supranational legal act that creates an internal market in the area of defence and security procurement; therefore, the focus is here on the economic benefit. Economic benefits deriving from an open defence equipment market would then be in the self-interest of a member state.

The defence market in Europe consists of a small number of sellers, and an open market would give governments the opportunity to more efficiently buy from a larger number of manufacturers. Concurrently, the aspiration to open the market for defence products and the removal of protectionist policies, would give the possibility for an improved position for national defence equipment manufacturers. Such an improvement is expected to follow from two economic factors in this new open market: economies of scale and increased competition. A first effect of opening up the EU defence equipment market is that the defence contractors benefit from a larger market by economies of scale. Manufacturers are then able to produce quantities at a lower average cost, which 
increases the supplier's margins. Secondly, on a larger market, free of trade barriers, the increase in competition will reduce product prices. This increase in competition can be expected to be in the interest of all member states studied here. Consequently, both these economic factors are expected to give member states the possibly to make cuts in their defence budgets or sustain the already reduced defence budgets (Blauberger and Weiss 2013, p. 1133).

When applying this approach to this case study, it is important to note that this economic benefit might look different in the four member states studied. The UK, France, Sweden and the Netherlands all have quite a different market shares in Europe, and the world (Mawdsley 2008). Similar, but distinct economic benefits are therefore expected to be found in the analysis. Member states are hypothesised to have changed their position because it was in their interest to have a Directive that was expected to lead to lower prices of defence products due to increased competition and economies of scale. In addition, those economic factors were expected to lead to an improved position of the European defence industry on a global level.

\section{Entrapment}

To study the change that occurred in the member states' position, a second perspective is also adopted: entrapment. Entrapment or shaming occurs when actors use norm-based arguments to justify a policy. To apply this perspective to this case study, two basic assumptions are adopted. Firstly, the assumption is that actors belong to a community with shared norms. In a community certain norms are existent that members agree upon or have created, and therefore make cooperation possible. When using this perspective, it allows hypothesising that member states changed their positon based on a norm. Secondly, the perspective assumes that the collective identity of members within this community is not expected to shape or change preferences (Schimmelfennig 2001, Thomas 2011) Even though actors will conform to what is appropriate in a certain setting, as common norms or previous commitments are a primary concern, they may continue to have different (national) preferences on a policy issue (Thomas 2011, p. 14). The collective is therefore seen as a separate part of an actor's identity, which can be used strategically. In institutional settings, actors are able to shame each other into complying with the obligations they have as a community member, because of adherence to what seems appropriate and legitimate in a certain community (March and 
Olsen 1998, Schimmelfennig 2001, p. 63; Thomas 2011). Actors can therefore consider to be entrapped into previously made decisions and community norms.

The EU is an international community with certain norms at its core (Schimmelfennig 2001, Thomas 2011, p. 13). From this perspective, it can be expected that member states within the EU will consider the community norms when making collective decisions. Furthermore, in the EU, the internal market has been one of the main drivers for integration and it is expected to be a (legal) norm to be followed by member states. Contravening internal market rules or not acknowledging the competence of the Commission in this policy field would be a high cost. A member in defiance of community norms questions their credibility.

The second assumption states that even though actors concede to the internal market rules, it will not shape their national preferences. Actors will follow community norms, but they might still have a national preference that differs from what is agreed upon in particular setting. In this case study, member states are expected to have changed due to the credibility attached to internal market rules. It is expected that member states acknowledge a cost of contravening this community norm, but continued to dislike the involvement (and increased role for) the Commission.

To consider if there was entrapment at play, the analysis will first establish the framing of the Directive into an internal market issue. Framing, in the analysis, is then not considered to be a separate mechanism, but as a prerequisite for entrapment. To use framing in this way is a means to clarify that the Directive was indeed proposed as an internal market issue. The hypothesis following this perspective is that member states changed their position because it would be a high cost to contravene the internal market rules. In addition, it is expected that member states chose to comply with internal market rules but continued to disapprove of supranational integration in this policy field.

\section{Data and method}

The analysis is based on official documents from both the Commission and member states during the period 2004 to 2007. The official documents consist of discussions from the national parliaments on the proposal for a Directive. These include parliamentary reports, studies and reports on the competence of the Commission, and official statements on defence procurement from the national governments. Furthermore, 16 semi-structured interviews were conducted in these four countries with 
officials who were in office between 2000 and 2007. Similar questions were asked in each country to unveil the national context of each selected state. Consequently, those responses give insight in the informal negotiations between the Commission and member states during this time. The interviews provide, together with secondary literature, the possibility of triangulating the findings of the official documents (Bennett and Checkel 2015, p. 28).

The method that is used for the analysis is process tracing (Bennett and Checkel 2015) Process tracing, gives the possibility to study the change in the position of member states on the Directive in retrospect and to isolate analytical categories that can account for the dependent variable (the member states position on the Directive). Whilst these analytical categories might empirically overlap, these distinctions are based on the analytical framework introduced above and expected to look as follows (Bennett and Checkel 2015, p. 30; Schimmelfennig 2015). The rational choice perspective would be confirmed by a change in the expectation of certain economic advantages over time. For example, from 2004 until 2007, member states officials indicate that either during this period the economic benefit of an open defence market was discovered and that therefore preferences changed. Such might be expected to have occurred through, for example, studies on the implications of the Directive. Or, it might be that these economic benefits were known, but that the significance of these benefits increased during this period of time. Secondly, entrapment can be confirmed by finding that member states did not change their initial reluctance about the involvement for the Commission, but accepted the proposal because of the validity of previous commitments to the internal market. In order to establish such an argument, it is also significant to find if and when the Directive was framed as an internal market policy. If member state officials indicate a sense of obligation to respect internal market rules, it can be assumed that these rules entrapped member states into changing their position. For the period from 2004 to 2007, both sets of arguments have been traced and analysed.

\section{State sovereignty in the European context}

An open European Defence Equipment Market was welcomed by all member states. This is demonstrated by the acceptance and signing of the EDA Code of Conduct on defence procurement (EDA 2005). In this voluntary treaty, all subscribing member states expressed the wish for increased competition, transparency and accountability 
(European Union Committee 2004-05). The main objective was to become internationally competitive. The open market was also welcomed in the response of the member states to the Green Paper (Tweede Kamer 2004-2005, European Standing Committee B 2005). However, most member states were against a Directive. Why did member states accept a Directive?

\section{Change based on expected costs and benefits?}

The opening up of the EDEM through a Directive could be expected to lead to two economic benefits, namely, an increase in competition and economies of scale. Both these economic effects will then possibly lead to lower prices for defence products. The expected economic benefit for member states would then be lower defence budgets following from cuts in expenses due to lower prices. Not only can these dynamics be expected to lead to more competition and efficiency within Europe, but it would also make the European defence market more competitive on the world market. Such ideas have also been part of the creation of the internal market within the EU (Internal Market Strategy 2003). Through the disappearance of border control and the creation of the socalled four freedoms, goods are able to flow freely among the different member states, thereby increasing competition not only within the EU, but also making European producers more globally competitive.

By having a larger market to sell defence products to, average productions costs can be expected to decrease. This possibility can also be expected to apply to the defence equipment market. Lower product costs is in the interest of defence ministries as in the last decade there is a stronger wish to stretch their defence budgets as far as possible (Interview British official, 1 May 2015). "If a member state can buy the cheap and better product from for example Germany, rather than the expensive and ineffective product from a national manufacturer, it will save expenses on the national defence budget" (Interview British official, 1 May 2015). The opening of the market will therefore not only give the national industry an opportunity to do business somewhere else in Europe, but also give European governments the possibility to buy defence material at competitive prices (Interview Swedish official, 14 April 2015, Swedish official, 8 June 2015). In the case of Sweden, the support for a more open market stems from the internal modifications Sweden made in its defence industrial policy, prior to the Directive (Britz 2010). The possibility to contain a reduced defence budget, or to 
make even deeper cuts, made possible by the Directive, were viewed as a benefit, and perceived similarly by all member states (Interview British official, 1 May 2015).

Furthermore, with the opening of the market it was expected that there would be an improved competitive position for the national defence industry of the countries studied. Here it is important to keep in mind that there are differences among the countries analysed in this paper. The UK and France are main and large producing member states and have a significantly different position on the defence equipment market in Europe and the world. The Dutch industry and the Swedish industry are considerably smaller. Sweden expected that their national defence industry could be kept intact by opening up the market. The risk of losing this national industry would be that a member state becomes more dependent on foreign companies to deliver those goods (Interview Swedish official, 14 April 2015).

As for the Netherlands, the expectations mainly centred on the opportunities the Directive would create for the Dutch defence industry (Interview Dutch official, 18 February 2015, Dutch official, 24 February 2015). Through the establishment of an open defence market, it was expected that Dutch companies would be able to enter the European market more easily. The Dutch defence industry is known for its large amount of SMEs, unlike the French or the British. Those Dutch companies could then benefit from the larger market for with SME. The response of the Dutch government to the Green Paper of the Commission in 2005 was positive (Interview Dutch official, 25 March 2016). In particular, it stressed this expectation that the Directive and the creation of an open defence market were expected to give the SMEs in the Netherlands better market access. The same expectations can be found in documents in the subsequent years (Tweede Kamer 2004-2005, p. 7, Tweede Kamer 2006-2007). These findings illustrate that there was no change in the expectation of an improved position for the national Dutch industry over this period of time.

The UK, as a leading European defence exporter, was a strong advocate for an open defence equipment market (Interview British official, 19 April 2015). Such was to be achieved through the EDA (European Union Committee 2004-05). An open market was expected to bring increased competition for the national defence industry. The UK assumed that the open market would create positive opportunities for the industry (European Standing Committee B 2005, Interview British official, 21 January 2015). A larger market share for British defence companies was furthermore expected to lead to the possibility to generate more employment and secure votes in the long run (Interview 
British official, 20 January 2015). This view is also reflected in the British response to the Green Paper which stated that the "measures that help to open up the European defence equipment market, and improve the competitiveness, and efficiency of European defence industry have the potential to bring significant benefit” (MoD 2005). The UK was aware that the inefficiencies and constraints in the European defence equipment market were caused by national policies of protectionism. Yet the government took the view that they could fight their own battles in gaining access to export markets (Interview British official, 20 January 2015). The official position of the British Government was that the potential benefits did not outweigh the drawbacks (European Standing Committee B 2005, European Scrutiny Committee 2006). A Directive would mean a burden on the already existent structure and not make the defence market more effective and efficient (European Union Committee 2004-05, European Standing Committee B 2005). Different than France, the Netherlands and Sweden, the UK openly addressed the expected costs of new regulations.

The discussions between the French Ministry of Defence and the Commission (DG Enterprise) before 2005 included the possibility of buying goods in an open market (Interview French official, 28 July 2015). Free trade would be good, for both the budget of the Ministry of Defence, and the SMEs in France. For France, the main concerns during these informal meetings with the Commission were the scope of the Directive. French officials had instructions to make sure that the Directive would not unnecessarily touch upon the sovereignty of the state (Interview French official, 28 July 2015).

Finally, member states expected that the Directive would aid in the common goal of being able to compete globally. Through cooperation and integration in the field of defence procurement, European member states would be able to make sure that their defence industry would continue to be competitive on a global level. "We believe in an open, market liberal and transparent market, because otherwise we cannot have a competitive industry in Europe that actually will be globally competitive and survive in the long run” (Interview Swedish official, 14 April 2015). In order to provide for defence material in the long run, the European defence market needs to be innovative (Interview Swedish official, 8 June 2015). For both innovation and global competitiveness, the national level is too small a market for defence (Interview British official, 1 May 2015, interview Dutch official, 24 February 2015). In the area of defence procurement innovation and competitiveness are important, as Europe aims to 
keep up with technological developments elsewhere. In addition to the expected lower costs for defence material and an improved competitive position of the national defence industry, member states acknowledged the necessity to be competitive on the global market (Tweede Kamer 2006-2007, Interview Dutch official, 29 May 2015). It was expected that the Directive would aid in this common goal.

Evidently, France, the UK, the Netherlands and Sweden welcomed the expected increased competition and the national defence industry improvements the Directive was expected to create. This improved position goes together with the expectation of savings on the acquisition of defence material. These savings were welcomed by all member states studied. In addition to these findings, the UK highlighted that the possible economic benefits would not outweigh the expected costs. The country did not expect efficiency and effectiveness from a Directive, due to an increase in regulations and administrative burden. However, this study aims to account for the change in position of member states that took place between 2004 and 2007. The analysis deciphers that expected economic benefit remained constant between 2004 and 2007 and can therefore not explain the eventual acceptance of a supranational policy. This consistency in expectations is most evident in the interviews and documents of the UK and the Netherlands, where similar arguments are used throughout this period of time. These findings of consistency cannot explain the move to supranational integration in this policy field. The perspective in this case study therefore fails to explain the change in the member states' position.

\section{Entrapped?}

To consider if member states were entrapped to accept the Directive, this section focuses first on the reframing of the policy. The internal market frame was established by positioning the policy within the DG Internal Market and Financial Services. The analysis then discusses the weighing of costs (or shaming into) with regards to conceding to the internal market rules. And finally, this section sheds light on the change of position, yet the continued unwillingness of member states to let the Commission have a role in this field.

After a Resolution from the European Parliament in 2002, the Commission proposed a plan for placing the defence equipment policy within the Community (Communication 2003). The Communication was produced by the Directorate General External Relations and discussed in the Council under competitiveness; however, the 
Green Paper (2004) was produced by DG Internal Market and Financial Services. The move of the issue to a different DG can be explained by the inauguration of the first Barroso Commission in 2004. With the start of a new Commission cabinet, a reshuffling in policy issues took place, whereby defence procurement was moved away from External Relations. The move of the policy to DG Internal market and Financial Services is a significant one, as it was the first time the idea for a Directive was introduced which positioned the future Directive in the field of the internal market, and framed the issue as such. The successful reframing was possible because of internal changes within the Commission and, as others have argued, the development of for example case law in the years leading up to the introduction of the Directive (Blauberger and Weiss 2016).

In the years thereafter, the Commission progressively continued to set the scope for the internal defence market. This was done through the results of the Green Paper consultations, published in 2005, and through an Interpretative Communication, that established the legal boundaries of article 296 TEC (346 TFEU). This communication addressed the specific conditions under which - according to the Commission member states would be able to make use of this derogation from the Treaty (Interpretative Communication 2006, Interview Swedish official, 14 April 2015). By limiting the different interpretations of article 346, the Commission issued that defence procurement clearly belongs in the internal market and that those legal obligations should be adhered to (Interview Swedish official, 14 April 2015; Interview British official, 21 January 2015).

The placement of the Directive within the area of internal market also made a shift in how member states perceived the proposal. This is evident in a report from the House of Lords where the then Minister for Defence Procurement (2004) stated:

As far as the legislative competence in the defence and security field is concerned, we do not believe the Commission has, strictly speaking, any competence. This remains within our competence, member states' competence, and we believe the Commission understands that (European Union Committee, p. 28).

In the field of defence and security policy, the Commission has, strictly speaking, no competence as the British minister would have it. The Commission does, however, have competence in the area of the internal market (article 3 and 4 TFEU). 
The position of the UK on the Directive changed after the understanding that this was an internal market issue and the Commission had competence: "The big legal issue was whether they had competence. And the legal advice was that they had competence because it is a single market issue” (Interview British official, 20 January 2015). Officials indicate that the delegation became more active in approaching and advising the Commission on the Directive (Interview British official, 20 January 2015). The UK tried to resist the proposal for a Directive as long as they could, but it became inevitable once the proposal was put within the internal market and British officials had to deal with the work provided by the Commission (Interview British official, 19 April 2015). Contravening the rules of the internal market and the legal competence of the Commission in the field would undermine the importance and the credibility of the internal market commitments.

It was not only for the UK but also for other member states that a shift occurred when they became aware and had the confirmation that the Commission had legal competence in the field of defence and security procurement (Interview British official, 20 January 2015). For some member states it was not until after the proposed Directive reached the Council that they requested the Council's legal department to provide a confirmation of the Commission's legal power to propose the extension of internal market rules into the area of defence procurement (Muravska 2014). The Council confirmed that the Commission had that kind of power.

The credibility attached to placing the DSDP within the internal market is emphasized by a Dutch official, who argues that the ambition of the Commission was to treat the defence market as a normal internal market issue. "And so [the Commission declared], we accept that there are specific issues within that market, and we will put these into the Directive. And that is what eventually happened” (Interview Dutch official, 18 February 2015, author's translation). The Commission was convinced that intergovernmental solutions were not enough to establish the EDEM and perceived defence procurement from the point of view of the internal market (Interview Dutch official, 24 February 2015; Dutch official, 29 May 2015; British official, 21 January 2015).

In arguing that member states had a sense of obligation to respect internal market rules in this particular case, there is an important distinction to be made between member states being coerced into following internal market rules, or voluntarily acknowledging such rules. Even though internal market rules may have entrapped 
member states, because of a high cost to contravene, they still had to possibility to voluntarily abide to such norms. The member states could have blocked the proposal at any time, but chose not to do so. An example of such threat could be the case law from the ECJ with regards to article 346 TFEU (Blauberger and Weiss 2013). However, an UK official makes it very clear that this was not a main concern:

It was a former minister and we wanted to do something uncompetitive with France. And the minister said, "But we will have trouble with the Commission." And I suggested to him we should test it. Just to see what happened. Because I was pretty sure, I am still pretty sure we would get away with it. Getting away with it sounds slightly wrong. I think their bark is worse than their bite (Interview British official, 20 January 2015).

In addition, a French official stated that France voluntarily entered into the discussions. During the informal discussions between the Commission and the French Defence Ministry, prior to the draft of the Directive, it was clear that France had two choices: either enforcing the use of 346 TFEU and thereby telling the Commission that defence procurement was none of their business; or "the other option was to accept discussion with the Commission on the basic assumption that there would be at the end a modus vivendi which would limit the scope” (Interview French official, 28 July 2015). Both these findings highlight that member states were not forced to accept the proposal for a Directive. Member states acknowledged the internal market rules and voluntarily entered the discussions with the Commission. In the words of a Dutch official:

You can ask yourself, is it politically desirable for your country not to comply, because we are of course not against an open and internal market. Even if we are worried if the Directive is the right means to achieve that objective, we will not vote against [such a proposal]. This could possibly give a different signal than what we actually want (Interview Dutch official, 18 February 2015, author's translation).

The acknowledgement of the internal market rules had consequences for how member states perceived the policy issue: "So I mean, we approached it, and the way it was sold to our ministers essentially, opening up the single market is a good thing. That is why we are in the European Union” (Interview British official, 20 January 2015).

In the policy process, the internal market rules were considered decisive and could not be disregarded, yet the Netherlands, UK and France still indicate that their initial preference did not change. A British official explains: 
I cannot remember exactly what sort of regime they constructed, the focus was primarily on things where no one could put up a hand and say there is a real national security interest involved here. So I think to some extent there was a sense of, the way the Commission presented this is very hard to resist this intellectually as you like. But we are not happy that they should be poking around in this area (Interview British official, 1 May 2015).

Member states officials acknowledge that a "complete and total rejection of the idea of a Directive was perceived as undesirable” (Interview British official, 1 May 2015). In particular, as the Directive was created as an extension of the Public Procurement Directive (Interview French official, 5 May 2015; French official, 28 July 2015). Even though member states were not particularly welcoming a role for the Commission, the obligation to internal market rules was seen as undeniable.

I just know that of all the things that worried the UK at the beginning, continued to worry us at the end. So, our position did not change. Obviously, publicly you say yes we are going along with it. And we did. ... But our concerns never changed (Interview British official, 19 January 2015).

To summarize, the use of this second perspective allows us to gain insight into how important it was for member states to adhere to the rules of the internal market in the years that they changed their positions. Member states emphasize that they complied with internal market rules because this is viewed as desirable when being a member of the EU. The perspective as such answers the questions surrounding why these member states accepted the proposal of a Directive based on a sense of obligation to respect community norms. The analysis has in addition uncovered the paradox of the aspiration to respect internal market rules, yet not fully embracing the involvement of the Commission. The change that took place between 2004 and 2007 inherits, therefore, a contradiction: member states want to have an open market as long as they themselves can decide when and how to use it.

\section{Entrapment revisited}

At first sight the puzzle of this case study can be answered by using the idea of entrapment. However, there are limitations to this perspective. Previous research has dealt with these shortcomings and has suggested that the theory is not specific enough in explaining underlying mechanisms that can capture or explain why actors voluntarily adhere to a certain norm (Sjursen 2002). The entrapment allows for understanding that 
actors can be led by community norms. In this case, member states acknowledged the validity of internal market rules. However, the perspective does not explain why member states would want to yield to the rules of the internal market if they are not forced to do so. The finding that member states voluntarily accepted the Directive and were not coerced into acceptance has been established above. Furthermore, member states indicate that there is a cost related to non-compliance, that is, losing credibility within the community. If a cost is indicated, it has something to do with the norm itself; the question then is why this norm is so important. The voluntary compliance and the importance of the norm are two specific problems that cannot be resolved when using the understanding of entrapment.

The above limitations ask for a stronger theoretical underpinning in understanding the change studied in this paper. Even though the entrapment may be correct in empirical terms, as it explains that member states followed previous made rules, a theoretical puzzle remains. One way forward in resolving this problem is by drawing on a communicative action perspective. This perspective holds that actors in a free and open debate argue in relation to inter-subjective standards. It is acknowledged that actors do not exist in mere vacuum, but in relationship with other actors. This shapes the actions and arguments of actors. In contrast to the methodological individualism of a rational choice perspective, the theory acknowledges that "the existence and validity of social norms at the inter-subjective level and the ability to reach mutual understanding are the coordinating mechanisms” (Eriksen and Weigård 1997, p. 221). One of these is the principle of consistency between what actors say and do (Eriksen et al. 2005, p. 240). An expectation of consistency has therefore a normative underpinning, because it's based on a common belief that actors ought to respect this principle.

This paper exposes how member states changed their position, that is, the move from mere reluctance towards the Commission proposals to accepting the Directive. In addition, the analysis points to inconsistencies in the position of member states studied. Previous to the Directive member states indicated the preference for intergovernmental solutions and the findings of this paper highlight that even after the acceptance of the Directive, such preferences continued to exist. This kind of preference is expressed in word; however, the move and acceptance of a supranational legal framework is a clear action towards more integration in the field of defence and security. The preference for intergovernmental cooperation is not reflected in the eventual acceptance of the 
Directive; therefore, the principle of consistency is violated. In addition, this inconsistency is already found in the response of member states to the Green Paper of 2004. The responses of member states were filled with double messages. In these replies, member states both welcomed the initiatives from the Commission but at the same time highlighted the preference for intergovernmental solutions (Représentation Permanente 2005; MoD 2005).

You have this paradox when dealing with defence material. Which is very sensitive and you would really like to have, hold close to your body. (...) It is very easy to talk about it, you have nice words, you sing songs together, but when it comes down to it, you are a bit reluctant really to be transparent (Interview Swedish official, 16 January 2015).

And finally the observation, which goes beyond the scope of the current analysis, that there is the inconsistency to be found in the practice of the Directive. Due to different factors, such as different cultures, it is hard to integrate the practice of procuring defence (Interview British official, 21 January 2015). Therefore, as the Directive is accepted and sets a standard in the field, the practice of this standard is much more difficult.

And so what we will do, we will go along with this, we will join their discussion groups, and we will participate in the drafting of the Directive, and have our lawyers be very careful that nothing is done which contradicts the ultimate big bazooka of our national security interest. And then when the Directive finally comes into force we will ignore it (Interview British official, 1 May 2015).

\section{Concluding remarks}

This article contributes to the growing literature on the influence of the European Commission on the CSDP of the EU. It does so, in particular, by analysing why member states changed their position on the Defence and Security Procurement Directive. The idea for a Directive was rejected in 2004, but a proposal was accepted in the Council in 2007. In order to tease out why member states allowed for a supranational legal framework in a field so closely attached to their sovereignty, the paper moves beyond current findings by providing new data from the UK, France, Sweden and the Netherlands. Using process tracing, the paper finds that a rational choice perspective, often used to explain European integration, fails to account for the acceptance of a Directive. The cost-benefit calculations, based on economic benefits, 
were not significantly changed during this period of time to explain the outcome and acceptance. After the first introduction of an idea for a Directive in 2004, however, member states' documents highlight the acceptance and discovery of the Defence Directive belonging within the Internal Market policy. By using an understanding of entrapment, which allows for an analytical distinction between interest and norms, the paper finds that the member states studied found it a high cost not to comply with rules existent in the internal market policy. These findings suggest that contravening previously made commitments regarding the internal market of the EU was expected to lead to a loss of credibility as a member of the European community.

The empirical implications of these findings are twofold. On the one hand the acceptance of the proposal for a Defence Directive suggests that member states have possibly come to view the norms existent within the Union more important than the norm of sovereignty. These findings suggest that even in the field of defence and security, member states wish to adhere to these norms, as, for example, internal market rules. In addition, the findings of this paper support studies that have contested our knowledge about the role of the Commission in the defence and security policy, demonstrating that the acceptance of the Directive clearly marks the beginning of the Commission gaining foothold in this policy field.

Theoretically, the findings in this case study resolve why member states changed their position, but also call for the need for alternative explanations that are not based on a rational calculation only. The paper introduces the shortcomings of the use of entrapment and suggests that a way to solve the problems posed by this understanding can be resolved by a communicative perspective. Therefore, the study indicates that it is important to develop and make use of theoretical tools that can explain why integration in this field happened, is possible, or why this particular policy is delegated to the Commission. Further research should explore the continual involvement of the Commission in this field to reveal the extent to which the practice in the field of defence procurement has changed.

\section{Acknowledgements}

A previous version of this paper was presented at the NoPSA Conference in Gothenburg in August 2014 and I want to thank all the participants for their comments. Thank you to two anonymous reviewers for their helpful comments. In particular, I am grateful to 
Helene Sjursen for all her help and constant encouragement. Many thanks also to the Norwegian Ministry of Defence for financing this research. This article is part of the EuroDiv project at ARENA, a research project financed by the Research Council of Norway’s research initiative ‘Europe in Transition’ (EUROPA).

${ }^{1}$ The Directive was proposed together with a Transfer Directive in a package consisting of both directives and a 'Strategy for a Stronger and more Competitive Defence Industry' (Communication 2007)

${ }^{2}$ Article 346 TFEU (ex Article 296 TEC) 1. The provisions of the Treaties shall not preclude the application of the following rules: (a) no Member State shall be obliged to supply information the disclosure of which it considers contrary to the essential interests of its security; (b) any Member State may take such measures as it considers necessary for the protection of the essential interests of its security which are connected with the production of or trade in arms, munitions and war material; such measures shall not adversely affect the conditions of competition in the internal market regarding products which are not intended for specifically military purposes. 2 . The Council may, acting unanimously on a proposal from the Commission, make changes to the list, which it drew up on 15 April 1958, of the products to which the provisions of paragraph 1(b) apply.

${ }^{3}$ See also Trybus 2014, p. 13. 
References

Bennet, A., and Checkel, J.T., 2015. Process Tracing. From Metaphor to Analytical Tool. Cambridge: Cambridge University Press.

Blauberger, M. and Weiss, M., 2013. “If you can’t beat me, join me!” How the Commission pushed and pulled member states into legislating defence procurement. Journal of European Public Policy, 20 (8), 1120-1138.

Britz, M., 2010. The Role of Marketization in the Europeanization of Defense Industry Policy. Bulletin of Science Technology Society, 30 (3), 176-184.

Bundesrepublik Deutschland, 2005. Entwurf einer Stellungnahme zum “Grünbuch über die Beschaffung von Verteidigungsgütern”, IB3 - 270119.

Citi, M., 2014. Revisiting Creeping Competences in the EU: The Case of Security R\&D Policy. European Integration, 36 (2), 135 - 151.

Communication from the Commission. The Challenges facing the European Defencerelated Industry, a Contribution for Action at European level, COM (96)10, final.

Communication from the Commission to the Council and the European Parliament, the economic and Social Committee and the Committee of the Regions. Implementing European Union strategy on defence-related industries, COM (97)583, final.

Communication from the Commission to the Council, the European Parliament, the European Economic and Social Committee and the Committee of the Regions. European Defence-Industrial and market issues. Towards an EU Defence Equipment Policy, COM (2003)113, final. 
Communication from the Commission to the European Parliament, the Council, the European Economic and Social Committee and the Committee of the Regions. A Strategy for a stronger and more competitive European Defence Industry, COM (2007)764, final.

Communication from the Commission to the European Parliament to the Council and the European Parliament on the results of the consultation launched by the Green Paper on Defence Procurement and on the future of Commission initiatives, COM (2005)626, final.

Cornish, P., 1995. The Arms Trade and Europe. Chatham House Papers.

Cross, M. 2015. The European Defence Agency and the Member States: Public and Hidden Transcripts. European Foreign Affairs Review, 20 (2/1), 83 - 102.

Dijkstra, H., 2011. The Role of the Council Secretariat and the European Commission in EU Foreign Policy. Thesis (PhD). Maastricht University.

Eisenhut, D., 2009. Europäische Rüstungskooperation. Zwischen Binnenmarkt und zwischenstaatlicher Zusammenarbeit. Baden-Baden: Nomos.

Elster, J.,1986. Rational Choice, New York University Press.

Eriksen, E.O. and Weigård, J., 1997. Conceptualizing Politics: Strategic or Communicative Action? Scandinavian Political Studies, 20 (3), 219- 241.

Eriksen, E.O., Fossum, J.E., and Sjursen, H., 2005. Widening or reconstituting the EU. In: E.O. Eriksen, ed. Making the European Polity. Reflexive integration in the EU. London: Routlegde, 237 -252.

Eriksson, L., 2011. Rational Choice Theory. Potential and Limits. London: Palgrave Macmillan. 
Proposal for a Directive of the European Parliament and of the Council on simplifying terms and conditions of transfers of defence-related products within the Community, COM (2007)765, final

European Defence Agency,2005. The Code of Conduct on Defence Procurement of the EU member states participating in the European Defence Agency, 21 November 2005.

European Scrutiny Committee, 2006. European Defence Procurement, 25 October [online]. Available from: http://www.publications.parliament.uk/pa/cm200506/cmselect/cmeuleg/34xxxix/3402.htm [Accessed 6 November 2014].

European Standing Committee B, 2005. European Defence Equipment Market, 8 February [online]. Available from: http://www.publications.parliament.uk/pa/cm200405/cmstand/eurob/st050208/5 0208s01.htm [Accessed 10 December 2014].

European Union Committee, 2004-05, European Defence Agency. Report with Evidence, 16 March [online]. Available from: http://www.publications.parliament.uk/pa/ld200405/ldselect/ldeucom/76/7602.ht m [Accessed 6 November 2014].

Genschel, P., and Jachtenfuchs, M., 2013. Beyond the Regulatory Power? Oxford: Oxford University Press.

Green Paper. Defence Procurement, COM (2004)608, final.

Heuninckx, B. 2015. Defence Procurement and the European Defence Equipment Market : the Virtues of Kissing the Frog. Upphandlingsrättslig Tidskrift [online]. Available from: 
http://www.urt.cc/sites/default/files/UrT\%20Heuninckx.pdf [Accessed 20 Augustus 2016].

Hoeffler, C. 2011. Les politiques d'armament en Europe: l' Adieu aux armes de l'Etat nation?, Thesis $(\mathrm{PhD})$. Sciences Po.

Howlett, M., Ramesh, M., and Perl, A., 2009. Studying Public Policy. Policy cycles and policy subsystems. Oxford: Oxford University Press.

Internal Market Strategy - Priorities 2003-2006, COM (2003)238, final.

Interpretative Communication on the application of Article 296 of the Treaty in the field of defence procurement, COM (2006)779, final.

Lange, P., 1993. Maastricht and the Social Protocol: Why did they do it? Politics\&Society, 21 (1), 5-36.

March, J.G., and Olsen, J.P., 1998. The Institutional Dynamics of International Political Orders. International Organization, 52 (4), 943-969.

Mawdsley, J., 2003. The changing face of European armaments cooperation: Continuity and change in British, French and German armaments policy 19902000, Thesis (Phd). University of Newcastle upon Tyne.

Mawdsley, J., 2008. European Union Armaments Policy: Options for Small States? European Security, 17 (2-3), 367-385.

MoD Defence Contract Bulletin, 2005. Green paper on defence procurement. Feature Report, 3 (11), 11 May.

Moravcsik, A., 1998. The Choice for Europe. Social Purpose and State Power from Messina to Maastricht. Cornell University Press. 
Mörth, U., 2003. Organizing European Cooperation - the case of armaments. Oxford: Rowman \&Littlefield.

Muravska, J. 2014. The institutionalisation of the European Defence Equipment Market, Thesis (PhD). London School of Economics and Political Science.

Nämden för Offentlig Upphandling, 2004. EG-kommissiones grönbok om försvarsupphandling, 15 December 2005 [online]. Available from: http://www.konkurrensverket.se/upload/NOU-arkiv/pdf/2004-0143-22SKoms_gronbok_forsvarsupph.pdf. [Accessed 25 September 2014].

Official Journal of the European Union, 1997. Treaty of Amsterdam amending the Treaty on European Union, the Treaties establishing the European Communities and certain related acts. Available from: http://eur-lex.europa.eu/legalcontent/EN/TXT/?uri=CELEX\%3A11997D\%2FAFI

Official Journal of the European Union, 2012. Consolidated version of the Treaty on the functioning of the European Union. Available from: http://eurlex.europa.eu/legal-content/EN/TXT/?uri=celex\%3A12012E\%2FTXT

Øhrgaard, J.C., 1997. Less than supranational, more than Intergovernmental: European Political Cooperation and the Dynamics of Intergovernmental Integration. Millenium - journal of international studies, 26 (1), 1-29.

Political Union. Commission Opinion, COM (90)600.

Pollack, M.A., 1994. Creeping Competence: The Expanding Agenda of the European Community. Journal of Public Policy, 14 (2), 95 - 145.

Représentation Permanente de la France auprès de l’Union Européenne, 2005. Livre vert sur les marches publics de la défense, 25 February, MICA/182/2005. 
Riddervold, M. 2015. A humanitarian common policy through deliberation? On the characteristic of EU foreign policy. Thesis (PhD). University of Oslo.

Riddervold, M., 2015. (Not) in the Hands of the Member States: How the European Commission Influences EU Security and Defence Policies. Journal of Common Market Studies, 54 (2), 353-369.

Risse-Kappen, T., 1996. Exploring the Nature of the Beast: International Relations Theory and Comparative Policy Analysis Meet the European Union. Journal of Common Market Studies, 34 (1), 53-80.

Schimmelfennig, F., 2001. The Community Trap: Liberal Norms, Rhetorical Action and the Eastern Enlargement of the European Union. International Organization, 55 (1), 47-80.

Schimmelfennig, F., 2015. Efficient process tracing: analysing the causal mechanisms of European integration. In: A. Bennet and J.T. Checkel, 2014. Process Tracing. From Metaphor to Analytical Tool. Cambridge: Cambridge University Press, 98-125.

Security and Defence Agenda, 2005. Will the EU get tough on opening-up national defence procurements? SDA Reports, 18 April 2005.

Sjursen, H., 2002. Why expand? The question of legitimacy and justification in the EU's enlargement policy. Journal of Common Market Studies, 40 (3), 491-513.

Sjursen, H., 2011. Not so intergovernmental after all? On democracy and integration in the European Foreign and Security Policy. Journal of European Public Policy, 18 (8), 1078-1095.

Thomas, D.C., 2011. Making EU Foreign policy. National preferences, European Norms and Common Policies. London: Palgrave MacMillan. 
Trybus, M., 2014. Buying Defence and Security in Europe. The EU Defence and Security Procurement Directive in Context. Cambridge: Cambridge University Press.

Tweede Kamer der Staten-Generaal, 2004-2005. Nieuwe Commissievoorstellen en initiatieven van de lidstaten van de Europese Unie, 21 April 2005.

Tweede Kamer der Staten-Generaal, 2006-2007. Defense Industrie Strategie, 27 August 2007.

Weiss, M., 2013. Integrating the Acquisition of Leviathan’s swords? The Emerging Regulation of Defence Procurement within the EU. In: P. Genschel and M. Jachtenfuchs, eds. Beyond the Regulatory Power? Oxford: Oxford University Press, 26-45.

Weiss, M., and Blauberger, M., 2016. Judicialized Law-Making and Opportunistic Enforcement: Explaining the EU's Challenge of National Defence Offsets. Journal of Common Market Studies, 54 (2), 444-462. 